сохранение микроструктуры при повышении содержания ультрадисперсных добавок карбида кремния (рис.1, №6 и №7). Поскольку при повышении содержания ультрадисперсных добавок карбида кремния до 0,2\% происходит некоторое снижение микротвердости до 10185 - 12891 МПа, наиболее перспективным является модифицирование карбидом кремния до концентраций $1 \%$.

Таким образом, рассмотрены распределения химических элементов на поверхности всех исследуемых образцов. Выявлено, что в исходном образце наблюдается однородное распределение карбида вольфрама; в модифицированных материалах в зависимости от содержания ультрадисперсных добавок присутствуют вкрапления $\mathrm{Al}, \mathrm{O}$, $\mathrm{Si}, \mathrm{Mg}$. Установлено, что введение ультрадисперсных добавок приводит к уменьшению зернистости и колебаниям микротвердости, следовательно, к возможности управления микроструктурой твердосплавного материала опытных образцов буровых пластин.

\title{
***
}

1. Чапорова И. Н., Чернявский К. С, Структура спеченных твердых сплавов. -М.: Металлургия, 1975. $247 \mathrm{c}$.

2. Третьяков В. И., Основы металловедения и технологии производства спеченных твердых сплавов. - М.: Металлургия, 1976. - 528 с.

3. Савицкий Е. М., Поварова К. Б., Макаров П. В. Металловедение вольфрама. М.: Металлургия, 1978. 223 c.

4. Зеликман А. Н., Никитина Л. С., Вольфрам. -М.: Металлургия 1978. - 272 с.

5. Лебедев М.П., Винокуров Г.Г., Кычкин А.К., Васильева М.И., Махарова С.Н., Сивцева А.В., Федоров М.В., Довгаль О.В. Влияние ультрадисперсных добавок на микроструктуру и свойства вольфрамокобальтовых сплавов рабочих элементов буровой техники. Известия Самарского научного центра Российской академии наук. 2010. Т. 12. №1-2. С. 427-431.

\section{Киселев В.В., Хохолов Ю.А. \\ Температурный режим поверхностного курганного могильника твердых отходов в случае глобального потепления климата}

Институт горного дела Севера им. Н.В. Черского СО РАН (Россия, Якутск)

doi: $10.18411 / \mathrm{lj}-30-09-2017-23$

idsp: 000001:lj-30-09-2017-23

\section{Аннотация}

Представлен разработанный институтом способ захоронения твердых радиоактивных отходов с использованием технологий горного дела. Поверхностный курганный могильник представляет собой льдопородную конструкцию, сформированную из послойно уложенных, сцементированных льдом твердых радиоактивных отходов. Сделан прогноз температурного режима поверхностного курганного могильника твердых радиоактивных отходов в условиях глобального потепления климата.

Ключевые слова: Твердые радиоактивные отходы, поверхностный курганный могильник, температурный режим, глобальное потепление

Прогнозируемый рост среднегодовой температуры воздуха в северных регионах может привести, по оценке ряда специалистов, к постепенной деградации природных ландшафтов криолитозоны, исчезновению лиственничных лесов, ледников и т.д. С началом растепления многолетнемерзлых грунтов произойдет снижение их прочностных свойств, и в случае непринятия превентивных мероприятий начнется массовое разрушение многих народнохозяйственных объектов Севера, построенных по принципу сохранения мерзлого состояния пород: фундаментов, плотин, дамб, дорог, взлетнопосадочных полос аэродромов, опор ЛЭП и т.д. В чрезвычайной ситуации могут оказаться могильники твердых радиоактивных отходов (ТРАО), которые планируется 
возводить на дезактивированных территориях аварийных подземных ядерных взрывов на территории Якутии.

Могильник ТРАО представляет собой искусственный курган, возведенный в зимнее время способом послойной укладки ТРАО (почвенный слой, растительные остатки, грунт, донные отложения водотоков) с утрамбовкой и поливом водой, и промораживанием естественным холодом [1,2]. Поверх промороженных ТРАО последовательно возводят ледяной панцирь, сцементированные льдом суглинок и торф. Для расчета температурного режима могильника ТРАО используется методика расчета послойного намораживания пород при формировании льдопородного массива, которая учитывает все основные факторы: влажность (льдистость) ТРАО, толщину слоя, годовой ход наружной температуры воздуха и т.д. [3,4,5].

На основе разработанных программ для ЭВМ были проведены численные эксперименты по расчету прогноза температурного режима поверхностного курганного могильника ТРАО в условиях глобального потепления климата. На рис. 1 представлены графики температуры на поверхности ядра могильника ТРАО при различной скорости потепления климата.

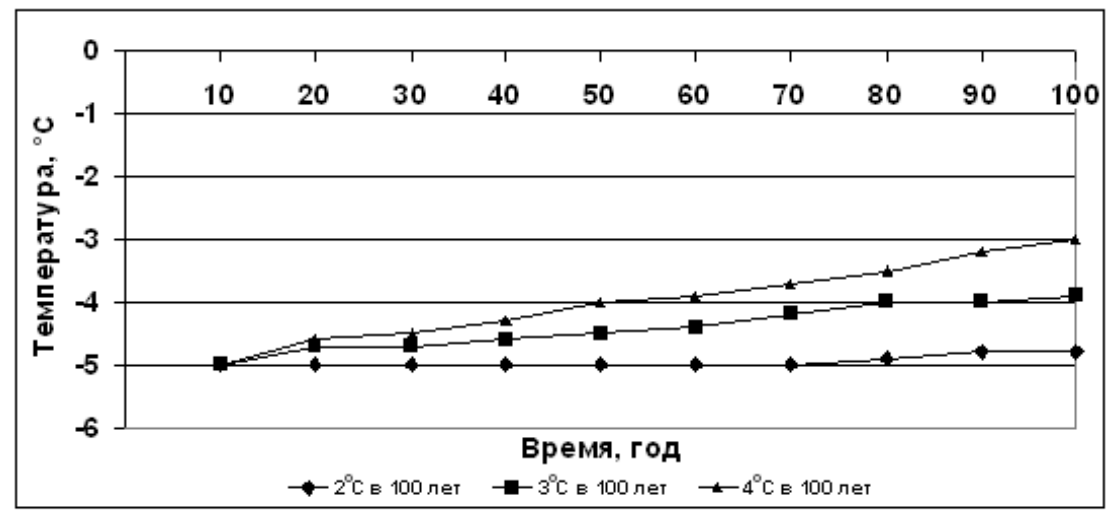

Рис. 1. Температура на поверхности ядра могильника ТРАО в зависимости от различной интенсивности потепления климата

Полученные результаты расчетов позволяют сделать следующие выводы:

Значительное влияние на температуру на поверхности ядра могильника при глобальном потеплении климата имеет толщина возводимого теплоизоляционного слоя.

Увеличение влажности (льдистости) укладываемых в могильник ТРАО повышает хладоемкость могильника, уменьшая тем самым негативное влияние растепляющих факторов в летнее время.

Теплоизоляционный слой, возводимый для предотвращения растепления могильника в летнее время, значительно снижает глубину протайки.

Предлагаемая технология укладки ТРАО в могильник, его конструкция, предлагаемые мероприятия по защите могильника от неблагоприятных факторов в состоянии обеспечить долговременную устойчивость (не менее 100 лет) при условии потепления климата на $1+3^{\circ} \mathrm{C}$ по сравнению с существующим, а следовательно изоляцию радионуклидов - одного из самых опасных для человека и окружающей среды чрезвычайных факторов.

$$
* * *
$$

1. Патент № 2134459 RUS, MПК6 G 21 F 9/24. Способ захоронения твердых радиоактивных отходов в зоне многолетней мерзлоты / Киселев В.В., Хохолов Ю.А.; заявитель и патентообладатель ИГДС СО РАН. №97113864/25; заявл. 12.08.97; опубл. 10.08.99; Бюл. № 18.

2. Киселев В.В., Бурцев И.С. Ликвидация последствий аварийных подземных ядерных взрывов в зоне многолетней мерзлоты. Якутск: Изд-во ЯНЦ СО РАН, 1999. 148 с. 
3. Каймонов М.В., Хохолов Ю.А., Курилко А.С., Необутов Г.П. Методика расчета послойного намораживания пород при формировании льдопородного массива в горных выработках // Горный информационно-аналитический бюллетень. 2003. № 9. С. 47-49.

4. Хохолов Ю. А., Мамонов А. Ф., Зубков В. П. Оптимизация формирования льдопородного массива в горных выработках Горный информационно-аналитический бюллетень. 2004. №10. С. 103-107.

5. Курилко А.С., Ермаков С.А., Хохолов Ю.А., Каймонов М.В., Бураков А.М. Моделирование тепловых процессов в горном массиве при открытой разработке россыпей криолитозоны. Новосибирск: Академическое изд-во «Гео», 2011. 140 с.

\section{Наумов И.В., Шевченко М.В., Кожушко П.П. \\ Влияние несимметрии фазных токов в электрических сетях напряжением 0,38 кВ на пожарную опасность в жилых и производственных помещениях Амурской области}

Дальневосточный государственный аграрный университет (Россия, Благовещенск)

doi: $10.18411 / \mathrm{j}-30-09-2017-24$

idsp: 000001:lj-30-09-2017-24

\section{Аннотация}

В статье представлен анализ влияния несимметрии фазных токов на пожарную опасность в жилых и производственных помещениях, и даны рекомендации по уменьшению количества пожаров связанных с неправильным распределением потребителей электрической энергии по фазам сети.

Ключевые слова: электрическая сеть,несимметрия фазных токов, ток нулевой последовательности, потребители электрической энергии.

Современный этап развития сельской электрификации характеризуется прогрессирующим ростом сельскохозяйственного производства и развитием коммунально-бытовой нагрузки - увеличением мощности нагрузок предприятий, развитием электротехнологии и автоматизации производственных процессов, а также повышением степени использования электрооборудования, в частности однофазных электроприёмников. В свою очередь, это влечет за собой постоянный рост потерь электрической энергии и мощности, как в распределительной сети, так и в самих электроприемниках. Одним из источников потерь, является несимметрия токов в сети и на зажимах электроприемников.

Основной причиной возникновения длительных несимметричных режимов электрических систем является несимметрия распределения потребителей электрической энергии по фазам сети. К таким потребителям в первую очередь следует отнести электротехнологические установки, преобладающее большинство которых, вследствие несимметричного исполнения и особенностей самого технологического процесса, обуславливает несимметрию режима питающей электрической сети, что отрицательно влияет на работу потребителей и ведет к ухудшению показателей качества электрической энергии. Подключение таких потребителей к электрической сети вызывает в последней несимметрию токов и напряжений, которая отрицательно сказывается на работе всех звеньев системы: генераторов, линий электропередачи и трансформаторов, приемников электроэнергии.[ 1 ]

Значительные токи нулевой последовательности, протекающие через нулевой проводник недостаточного сечения, могут вызвать его сильный нагрев. Сильный нагрев нулевого проводника приводит к однофазному короткому замыканию, что в случае неисправности или неверного выбора защитной аппаратуры приведет к возникновению возгорания.

Проведен анализ пожаров и их последствий в Амурской области за период 2006 2016гг в сельской и городской местности. Согласно данным предоставленным ГУ МЧС 